\title{
Обзоры
}

удҮ 577.157 .2

\section{А. А. Гершкович}

\section{МОЛЕКУЛЯРНЫЕ ОСНОВЫ ВЗАИМОДЕЙСТВИЯ ГИРУДИНА С ТРОМБИНОМ}

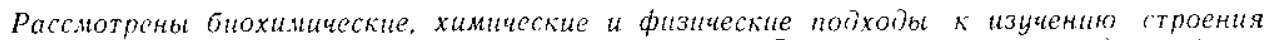

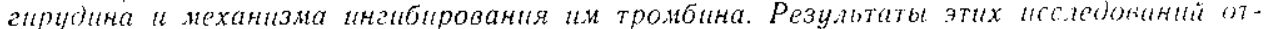
крьвант путь оля создания синтетических ингибиторов тромбина кового типа.

Введение. Тромбин (Е. С. 3. 4. 13) - ключсвой фермент систсмы свертивания крови на протяженин многих лет являстся объектом интенсивиых науцих исследований [1]. В сфсру изучения гемостаза попадают не только тромбин и друтие регуляторные фермснты, но также их природные и искусственные регуляторы - активаторы и ингибиторы. Среди природных ингибиторов тромбина лучшим является гирудин пебольиой бспок, производимый слюнными железами меницинкой пиявки, Hirudo medicinalis.

Гирудин хороцо связываетсял с тромбином $\left(K_{d} \sim 10^{-12}\right.$ моль/л $)$, прсдотвращаз таким образом распепление фибриногена и образование сгустка. Іестественио, ученые возлагают большие надсжды на нспо.'тзованис этого отличного антикоагулянта в ие,цицнскої практике.

Болсе 100 лет тому назал, в 1884 году, Д. Хэйграфт, работанший в Страсбурге, обнаружил, что меднцинскне пиявки содержат вещество, обладаюшес антикоагулянтной активностью [2]. В последующис годы врачи ислользовали водныс вытяжки из пиявок и только в 1904 го,у Якоби [3] вығегит неочищениый гирудин и дал ему пазвание, а очнстил и охарактерпзовал его в 1937 г. известный пемецкий ученый Маркпардт [4]. Осподным препятствием для использования lнрудниа в кинпике была сиожност, потуцения сго в больших копнчествах, поэтому

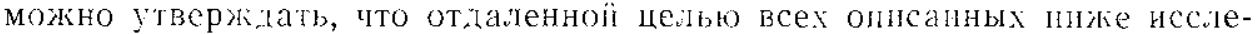
дованиї было полученте искусственным путем гпруднна нли сго аналогов и активных франментов. Эты работы имели такље важное зияте-

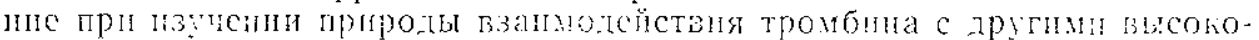

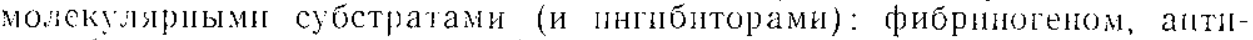
тромбином, гепарином, тромбомо:унином п др. [1]. Kроме того, они

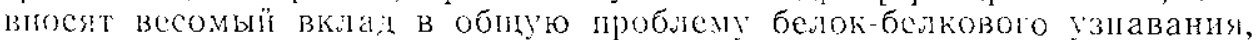

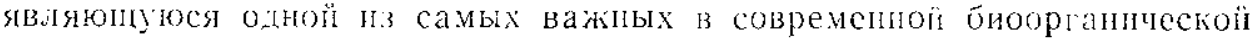
химин н молекулярной бнопогин.

Bвнуу того, что гирутн образует с тромбином высокоспецифическиї комштекс, пазнашспе отдельных деталей его строення может быть понято тоиько ири изучении пзанмодействия этих биополимеров. IІоэтому целссообразно юачат пан обзор с краткого из. жения структур-

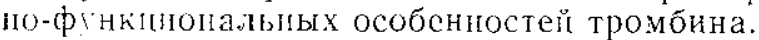

Протеолитическая специфичность тромбина. В пастоящсе премя тромбин хорошо изучен и описан в ряде монографий и обзоров $[1$, $5-7\}$. Он является трипсиноподобной протсазоӥ, но облалает болсе слабыми фермснтативными свойствами, чем трпнси, шри распеплении

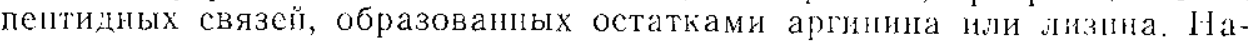
(C) А. А. ГЕРШКОВИЧ, 1992 
прнмер, тромбин расщспляет в своем главном физиологическом субстрате фибриногене только 4 из 376 чувствительных к действию трипсина связей (причем это четыре связи аргинин - глицин), что приводит К отщеплению двух пар N-концевых пептидов - фибринопептидов A « B от $\mathrm{A} \alpha$-и В $\beta$-цегей фибриногена, к образованию фибрина и его дальнейшей полимеризащин. Многолетние исследования позволили выяснить некоторые особенности стросния тромбнна, обусловливаюшие его высокую специфичность: «карман» первичного связывания хуже подогнан к специфнцеским субстратам, чем у трнпсина [6], рялом с

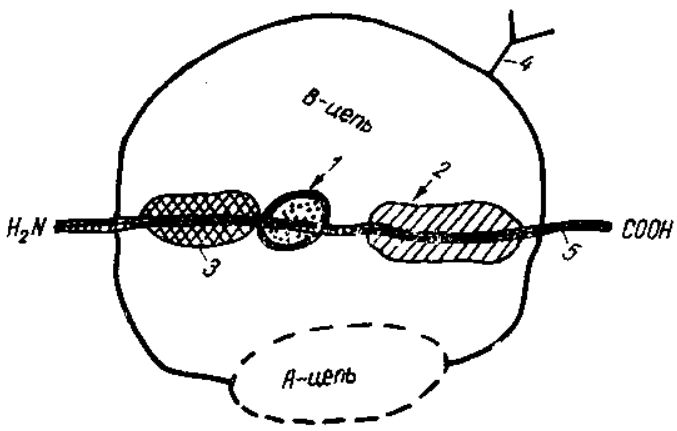
активным центром расположен вторичный алолярный связывающий участок, который вносит значитсльный вклад в катализ; кроме этих сайтов,

Рис, 1. Схематниеское изображенио связываюших участков тромбнна: I- -ксталитнисскй центр; 2-- аннон-связываюциї участок; 3 - аполярный связывающий участок; 4 -.. углеводная цепь; 5 - лептияныї суб. cтpar [8]

имеетя сше отдалениый участок связывания белковых субстpатов или «анион-связывающий участок» $[7,8]$ (рис. 1). Из-за перечис.lенных особенностей строения тромбин в общем плохо расщепляет связи, соотвстствющие только его первичной специфичности (опреде:пяемой остатками аргинина или лизина); лучше, если субстраты имеют ciesa от расшепяясмой связи (в положении Рз по классификации Шехтера и Бергера [9]) гицрофобную аминокислоту, которая взаимодействует с аполярпым связывающим центром (вторичная специфичность); и особснно эффективно - субстраты, взаимодействуюшие по всем трем указанын сайтам. Әтому трсбованию отвечает ф)ибриноген. Рентгењоструктурный анаяиз тромбина чсловека $[10,11]$ в цслом поптвердил наличие трех вышеуказанных связывающнх участков в молекуле и

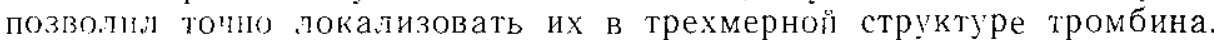

Особый интерес представляст удаленный от активного центра «аннон-связывающий участок», отсутствуюшиї в автолитических пропзво,цных тромбина - его $\beta$ - и $\gamma$-формах, что связывают с выщепленисм 13 илх основного пелтила - фраммепта В-цепи $63-74[1,6,7]$. Показательно, что $\beta$ - $\gamma \gamma$-тромбины расшенляют эфирлыс и амидные субстраты с такой же эффективностью, как и нативный $\alpha$-тромбин, однако при раслеплспи ими фибрипгена она уменынается до величины $\left(k_{c a t} / K_{M}\right)$, приб́пнзиельно в 2500 раз меньшей, чем в случае расшсииения о-тромбином [12]. Поэтому указанные фориы тромбина практически не обла,дар свертываюшей активностью. По-видимому, тот факт, что взанмодейстіне тромбина с гирудниом нзучалось почти во всех паборатория, исслекуюшых тромбин, связан с повышенным пнтсресом учепых нменио к строению и локализации «анион-связываюпего участка» в тромбннс.

Структурные особенности гирудина. І"нруднн, 65-членный бслок из 11. medicinalis, вперізые бы. очищсн и охарактеризован Марквардтом [4], а со аминокістотая носле,довательность установлена Додтом с coasт. [13] и уточнена Мао с соавт. [14] (рис. 2). Молекулярная масса rиру lина составляет 7000 и нссколько колеблется у разных исслсдоватсісі из-за существования трех типов гомологичных гирудинов: нан бoneе пзутенног HV1 [13], а также двух других форм-- HV2 [15] " IIV3 [16], гомопогия которых по первичной структуре состав:яет 85$90 \%$, притем все опи содсржат в С-концевой части молекулы сульфиpованыл тирознн. Вви,у того, что болъшинство исследователей работало с гирудином IIVl, мы булем называть «гирудином» именно эту 
форму, в случае необходимости уточняя, с какой формой проводили нслледования.

Гирудин является одноцепочечным белком, содержащим шесть остатков цистеина, соединенных тремя дисульфидными мостиками. По данным работы [14], в положении 33 полипептидной цепи скорее солержится остаток аспарагина, чем аспарагиновой кислоты. При рассмотрении первичной структуры гирудина обращают на себя внимание следующие ее особенности: на небольшом отрезке из 9 аминокислот (участок 55-64) содержатся 6 отрицательно заряженных остатков,

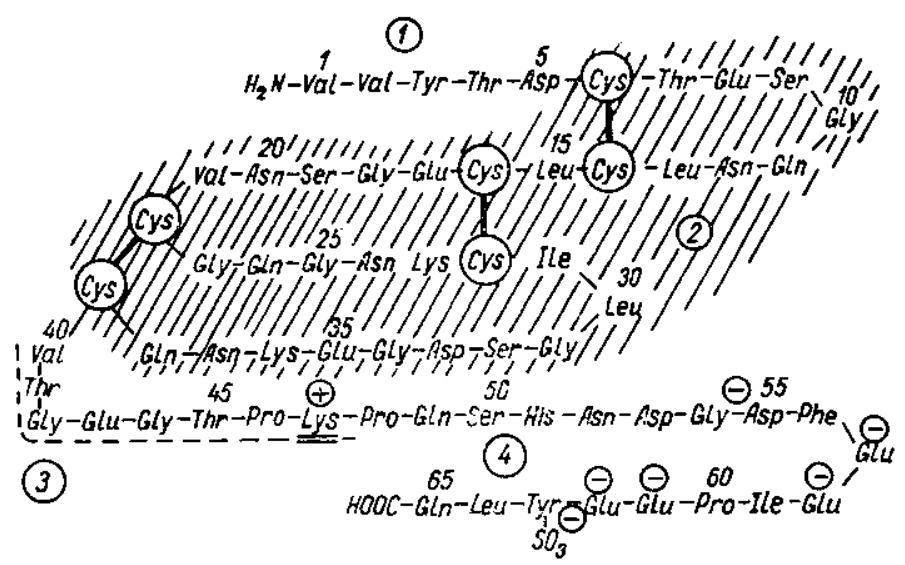

Рис. 2. Аминокислотная последовательность гирудина: $l$ - N-концевой фрагмент; 2 ценгральный кор; 3 - последовательность, гомологичная расщсплясмому участку в протромбине; 4 - С-концевой участок

включая сульфнрованый Туг-63; участок цепи $6-39$ представляет собоџ̆ компактшый кор, спитый дисульфидными мостиками, в то время қак C-копцевой участок $(40-65)$ in $\mathrm{N}$-концевая часть молскулы (1-5) ивляются поднижными относительно кора. Ченг [14] обратил внимание на обратпую гомологио участка $46-65$ с фибринопептидами А B, а Дегриз с соавт. [18] отметили гомологичность центрального yчастка гирухина 40-47 расщепляемому тромбином сайту в протромбине. Таким образом, простой анализ аминокислотной послсловатсльности позволил предположить наличие в гирудине по крайней мерс 'Lвух участков связывания с тромбином: отрицательно заряженного

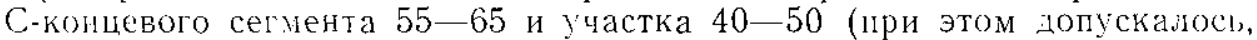
что остаток Lys-47 связывается в «кармане» активного центра тромбина [18]).

Анализ С-концевого участка по метогу Чоу и Фасмана [3] ronaзая возможность образования им $а$-спиральной конформации. Изображение этого сегмента в виде «колеса Ә;мушцсона» [3] цопускает всроятность формы амфифильной искажснной спирали, в которой все

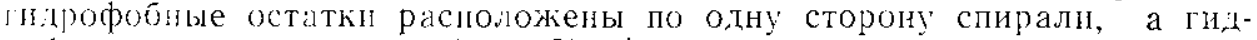
рофнаныне -.. по другую (рис. 3). Авторы этой работы предположнли, что такая амфнфильная спиральная структура С-концевого сегмента

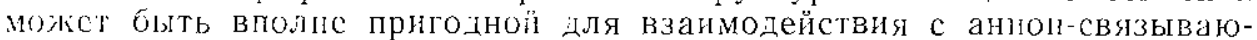
щим цештром тромбина.

Болсе существенные данныс о пространственной структуре гируцина полуген при его изученин методом ЯМР в водном растворе. Былl показано, что молекула состоит из трех доменов: центрального кора, состояшего из оста́тков $3-30,37-46$ н $56-57$; выступаюшего «штнфта» из остатков $31-36$, образующих антипараллельнуг $\beta$-структуру, п экспонированнои наружу петли, формируемой остатками сегмента 47-55 [19]. Структура каж;ого домсна относительно хорошо разрешена, однако орнептация двух минорных доменов относнтельно центрального кора не определена, так как в двухмерном ЯМР-спектре дальнодействующие протонные взаимодействия не наблюдались. Цсит- 
ральный кор стабилизируется тремя дисульфидными мостиками, имеются две $\beta$-структуры $(15-22$ и 35-42) и участки нерегулярного клубка $1-5,13-14$ и $42-65$ [20]. Так как расчеты методами молекулярной динамики показали возможность свободного перемещения двух минорных домснов относительно кора, авторы работы [19] предположили, что это может иметь функциональное значение: минорные $\mathrm{N}$ - и С-концевые домены способны действовать как «щупальцы» при связывании гирудина с тромбином.

Изучение структуры гирудина методом ЯМР позволило позднее полугить, дополнителыпые данные [21]. При изучении гриродного гирудина и его рекомбинантного аналога, в котором Lys-47 заменяли па
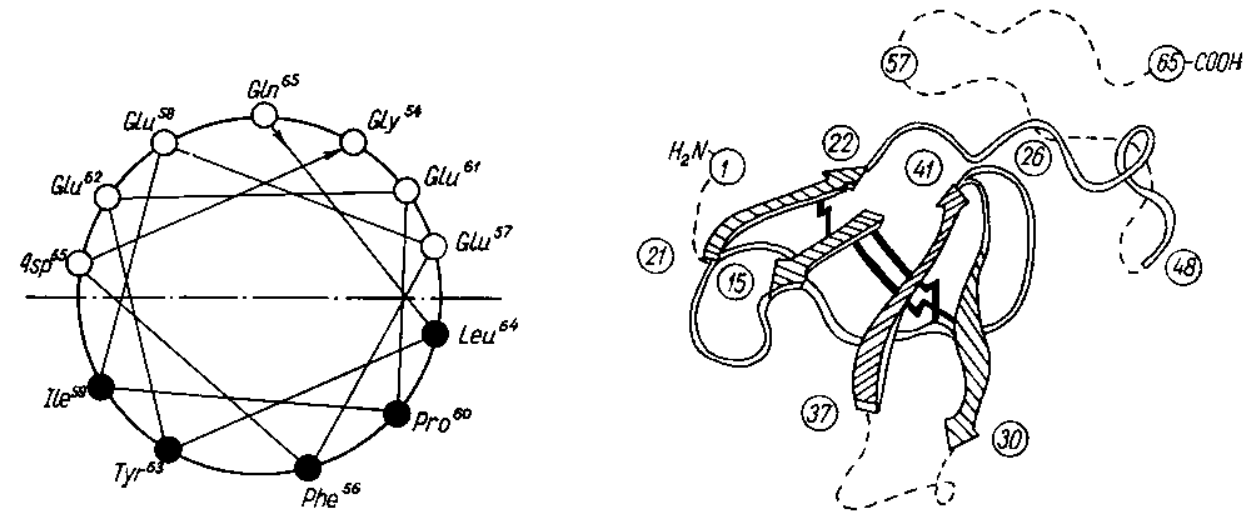

Pнс. 3. ilнграмма фрагмента гируднна 54-65 в виде «колеса эдмундсона», показы-

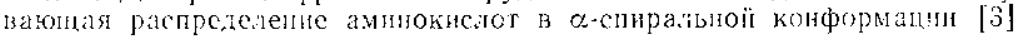

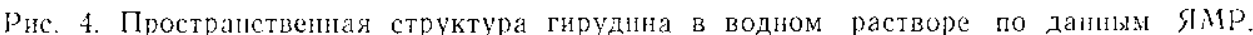
Стре.ткамн указаны $\beta$-скаддки; в виде ленты показны областы петель, образусмых го-

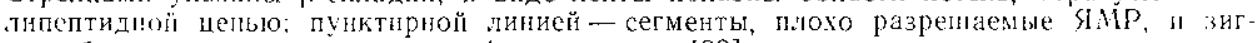

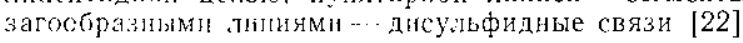

Glı (r-IIir-Gil-47), была хорошо разрешена структура фрагментов 230 п $37-\ldots 48$ и показано, тто произведенная замена остатка Lys-47 вызываст разґичимый, но очень слабый эффскт на пространственую структуру иолекулы.

Нзученис структуры рекомбинантного десульфированного гируди-

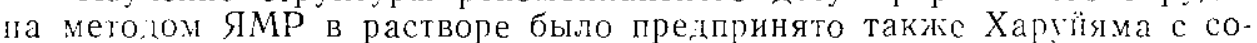
aвт. [22]. Полученназ ими картина очен похона на опнсаниую нами вынг: остатки 3 --30 п $37-48$ образуют плотный кор с двумя анти-

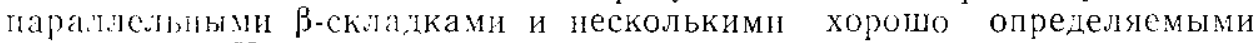
поворотами. Хороно идентифицированы также три дисульфигныс связи- 6--14, $16-28$ и $22-39$. Олнако метод не позволяет найті предшонпитеинуо конформацию фрагмента 49-65 іп петли, образуемой cетмитом 31 - 36. Пространственная структура гирудина, получнная на основании этих исследований, изображена на рис. 4.

Жсходя нз сведений о первиннй и вторнчной структурах гирудина (особениости пергичнй структуры, наличие $\beta$-складок, организация компактнго центрального кора молекулы и двух подвижных минорных $\mathrm{N}$ - и C-концевых доменов) авторы цитируемых работ могли выдвигать iово.льо правдоподобныс гинотезы о механизмах взанмодействия гирулина с тромбином, однако достоверными можно считать данные, попутенныс только в результате изучения взаимодеиствя этих молекул. B слелуюших разделах будет показано, как решалась эта задача с помопию комплекса современных методов нсследогания - биохимитесклх, химических и фнзических. Результаты таких исследований в настояшем обзоре изложены не в хронологическим порядке, а условно разнссены по разделам, так как такой подход, по мнению автора, хоропю иллюстрирует возможности каждого метода для решения задач белок-белкового узнавания. О цнако следует отметить, что работы с 
использованием разных подходов велись параллельно, дополняя и уточняя друг іруга.

Биохимические методы. В данном разделе изложены результаты изучения взаимодействия гирудин - тромбин как традициоными биохимическими методами (различные модификации фермента или ингибитора и т. п.), так и современными методами получения «мутантных» белков посредством сайт-специфического мутагенеза.

Прежле всего рассмотрим исследование влияния различных модифнцирующих агентов на способность гируцина сохранять связывающую активность по отношению к тромбину [23]. В этом случае использовали надмуравьнную кислоту, натрийборгигрид, диазометан, уксусный ангидрид, 2, 4-динитрофторбензол, циановокислый калий и некоторые другие агенты. На основании проведенных экспериментов был сделан вывод о том, что для эффективного ингибирования тромбнна в

Рис. 5. Влияние ионной силы на энергию связывания комллекса гирудин - тромбин 1 - природный гирудин; 2 - рекомбинант ный гирудин; $3-$ глутамин ${ }^{62}$-гирудин; 4-глутамин ${ }^{57,}$, 8-гирудин; 5 - глутамин $57,58,62$-гирудин; мин $57,58,61,62$-гирудин [24]

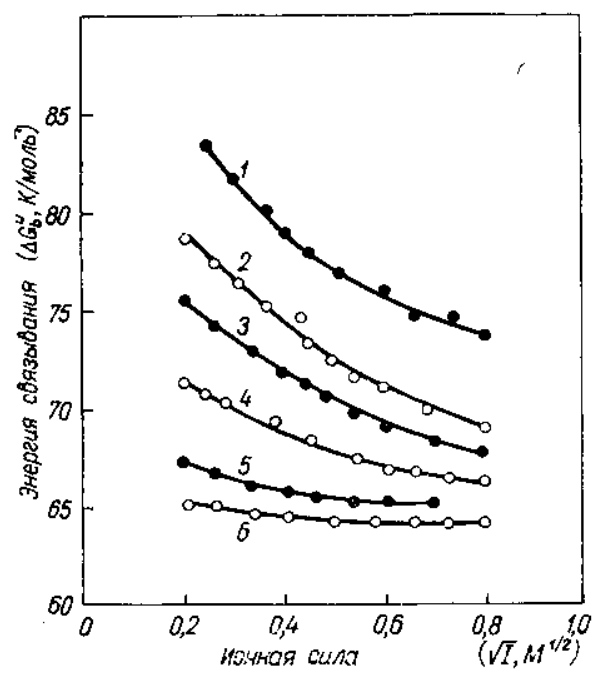

гирудине важна сохранность дисульфидных связей, а также наличие карбоксильных и, в меньшей степени, аминогрупп, что позволяет предположить важность компактной структуры центрального кора и существенпый вклағ в связывание электростатических сил. Кроме того, было показано, что остаток гистидина, по-видимому, более значителен, чем остаток тирозина и С-концевая аминокислота. Отмечено также, что пействие ға глрудин денатурирующих агентов $(50-100 \%$ этанола, $100 \%$ муравиной кислоты, $8 \mathrm{M}$ мочевнны и щслочи (pH 12)) не влияст на его способпость связываться с тромбином [29].

На осповании этих данных можно сделать вывод об устойчивости молекулы гирудина, которая обусловлена компактностью центрального кора, и репіющей роли этой структуры в физиологически важной конформации молекуль.

Для изучения влияния ионной силы па кинетику взаимодействия гирудина с тромбином Стоун с соавт. [24] исследовали взаимодсйствие различных рекомбинантиых гирудинов (r-Hir), которые отличались количеством отрицатепьно заряженных остатков в С-концевой части молекулы и содержали несульфированшый тирозин. В частности, сравннвалт связывание нативного гирудина (Hir), рекомбинантного гируднна и четырех сго аналогов, в которых остатки глутаминової кис-

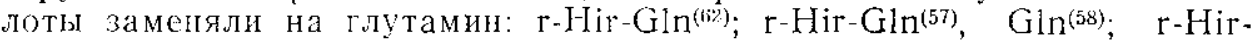

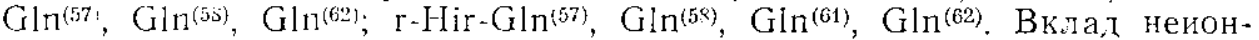
ных взанодейстий был одннаковым для всех тилов исследусмых соециненй, в то время как ионный вклад варьировал с изменением заряда молекулы (рис. 5) : каждый остаток глутаминовой кислоты давал приблизительно равный вкла.д -4 кДж/моль. Для нативного гирудина нопные взаимодействия составляют $32 \%$ от обшей связывающей энергии (при ионгой силе, равной нулю).

В работе [25] сделана попьтка разделить вклады во взаимодействие с гирудином в районе активного центра тромбина и его аниог-связываюшего участка. Для этого определяли константу диссоциации гиру.нн-тромбинового комилекса, варьируя концентрации гируднна при 
постоянных концентрациях тромбина и трипептидного хромогеніого субстрата. Зависимость константы диссоциации комплекса от концентрацин субстрата предполагает наличие у тромбина высокоаффинного связываюшего участка для субстрата, который можно илентифищировать с активным центром фермента. Константа диссоциации заметно зависнт от ионной силы (что подтверждает важность ионных взаимодействий) и скорость диссоциации комплекса не зависит от связывания субстрата в актнвном центре фермента (т. е., по-видимому, гируцин не взаимодействует с активным центром тромбнна).

Додт с соавт. [26] изучали кинетику образования гирудин-тромбпнового комплекса, используя различные рекомбинантные гирудины со слелующими заменами в аминокислотной последовательности: Ile-27, Glu-27, Ile-36, Glu-36, Ile-47, Glu-47, Leu-51 и Asp-51. Сравнительно с незалещенным рекомбинантиым гирудином отмсчалось значительное yнеличнне константы ингибирования при замене Lys-47 на глутаминовую кислоту и слабое ее изменение при замене других основных аминокислот. А́вторы работы [26] предположили, что чувствитсльность Lys-47 к модификации указывает на влияние этого остатка на стабильность комплекса, определяя возшожность его связывания со специфическим «карманом» активного центра тромбина. IIpe;(Ionaraeтся также, что большая скорость образования компискса и ее завнсниость от нонної силы свидетельствуют в пользу того, тто процесс этот является рсакцисй, контролируемой : иффузией, и включает ионные взаимодействия. Возможно, удалениый участок связывания с тромбином формируется протяженной поверхностыо гидрофнльных и заряженных остатков цептрального кора с С-концевым сегментом.

В одной из первых работ в этом направлении Ченг [17] показал, что удалсние С-концевых аминокислот $y$ пативнго гирудина ферментативным или химическим способами ведет к полной потере ингшбиторной активности, на основании чего делается вывод о большом знанении C-колценого cегменга. В этой работе предполагастся наличие в «реактивном» центре тирудина остатка Lys-4 $\vec{i}$, что свидетельствјет о періз)степеннй важности доменной структуры гирудина для взаимодействия с тромбнном.

Дегриз с соавт. [18] изучали влиянис замен в гирудине HV2 остатков, гомологиных гирудину HVl, - в положении 47 в нем находлтcя Asn, а в положении 35 - Lys. Были получены рекомбинантные ана-

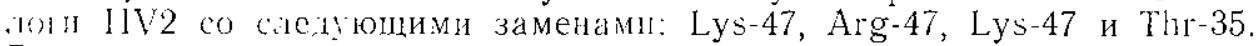
Ввиду того, что остатки в положення 35 и 47 находятся в сспменте 40--47, гомологином расщепляемому тромбином участку протромбина, предполагалось большос значение этого сегмента для связывания. Kıнелические иссле, иования показали, что константы диссоциации комп.екса прн замене Asn-47 на Lys или Arg уменьшаются в $5-14$ раз nо сравнению с немодифицированным HV2, в то время как замспа L.ys-35 виляния не оказығает. Авторы сиитают, что эти .данные под-

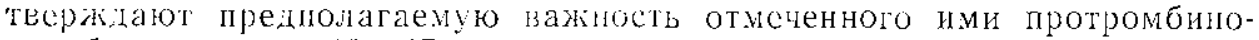
по, добного домена 40-47 L.19 связывания с тромбином.

В работе [27] изучено взаинодействие рекомбинантных гирудіпов, в которых каждый из трех остатков лизина и гисти, кин заменяли неїтральным остатком глутамина. Замена Lys-47 внесла незлачительное пзменсние в всличину константы диссоциацин комплекса (увелитенне в 9 раз), в то время как другие «мутацин были нсэффекінвнымн. Это указывает на то, что для гирудина в отличие от большинства другіх ннибиторов сериновых протеаз взанмодёіствие со специфиче-

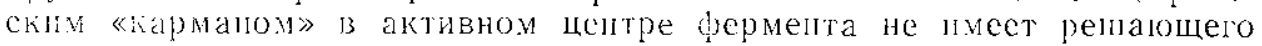

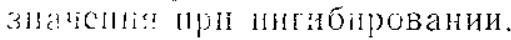

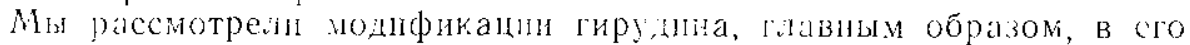

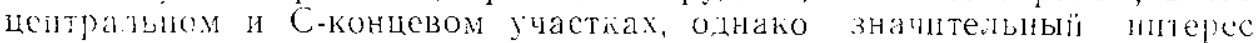

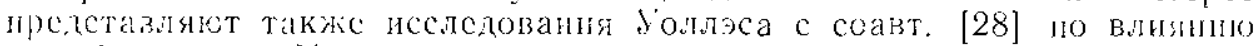

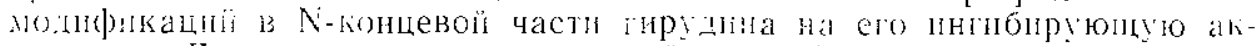

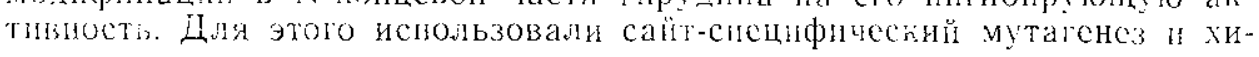


мические модификацин. В рекомбинантных аналогах гируднна одновременно заменяли Lys-27 на Gln, Lys-36 на Gln и Lys-47 на Arg и сравнивали сродство такого модифицированного по трем остагкам гирудина к тромбину со сродством его химических модификаций по концевой амнногруппе (уксусным ангидридом, ацетилимидатом и глицином). Ацетилирование аминогруппы, как и добавление остатка глицина, значительно повышало константу ингибирования (соответственно в 6,1 и 2,7 тысячи раз), в то время как ацетимидирование концевой амипогрушы (при этом сохранялся положительный заряд) увеличивало ее всего в 17 раз. При модификации незамещенного рекомбинантного гируднна остатками метионина или глицина $K_{i}$ возрастала соответственно в $2,4 \cdot 10^{t}$ и $2 \cdot 10^{3}$ раз. Особый интерес представляют данные по влияниг на $K_{i}$ замены гидрофобных остатков валина в положениях 1 и 2 полипептидной цепи (табл. 1). Замещение концевых остатков валина на гидрофильные аминокислоты значительно увеличивает константу ингибирования, тогда как замещение их гидрофобными остатками влияет пезначительно. На основания этих данных делается выводо важности положительного заряда на $\mathrm{N}$-конце молекулы дополнительно $\mathrm{K}$ его гицрофобности. Кроме того, в этой работе показано, что уменьшение гидрофобности N-концевой части молекулы гирудина снижает на $30 \%$ неионную составляющую связызающей энергии и практически не влияет па юонную. Анализируя высокий вклад концевого гидрофобного дипегтида в энергию связывания с тромбином, авторы [28] делают очень важное предположение о возможности контактов этой части молекулы с аполярным связывающим участком вблизи активного центра тромбина. Кроме того, они донускают, что в активном центре тромбина лолжен быть кислый остаток іля образования солевого мостика с концевои́ аминогруппой гирудина.

Цодт с соавт. [29] определили связывающие участки в тромбине дissl фрагментов гирудина 1--47 и 48-65, в которых остаток Pro-48 был заменен на $\Lambda$ la. Эти фрагменты получили расщеплением рекомбинантного гирудина (r-Hir-Ala 48 ) эндопротеиназой Lys-C. Они ингибировали свертывающую активность тромбина $c$ IC so $_{0}$ соответственно 0,6 и 4,9 мкмоль/л (для исходного $\mathrm{r}$-Hir она составляет 2,4 нмоль/л, т. е. соотвстственно в 300 и 2000 раз меньше). Было установлено, что С-концевой фрагмент 48-65 связывается тромбином на участке В-цени 62 74 - в районе анион-связывающсго участка, а $\mathrm{N}$-концевой фрагмент $1-47$ - с участком в райне $150-151$ В-цспи.

В работе [30] также использовали больпие фрагмспты рекомбинантного гирудииа, в котором остаток Asn-52 заменили на метионин, что позволило расщепнть его бромцианом на фрагменты r-Hiri-52 и r-Hir 53-65. Нзучали кинстику ингибирования этими фрагмснтами тромбина с целью идентификации участков, с которыми эти белки взаимодействуют друг с другом.

В результате взаимодействия фрагмснта 53-65 с тромбином про-

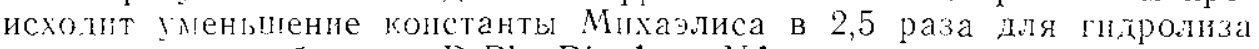
хрологеного cyбстрата D-Phe-Pip-Arg-pNA, что, по мнению авторов,

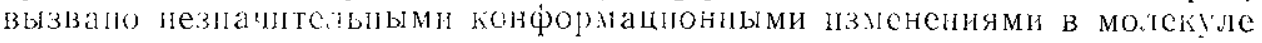

Т а 6 .

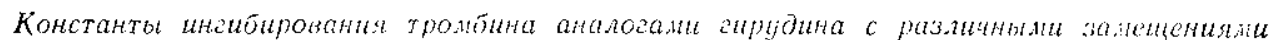

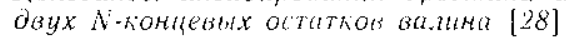

\begin{tabular}{|c|c|c|c|}
\hline Форма гирудпиа & 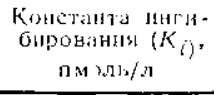 & Форман гирудина & 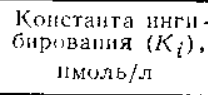 \\
\hline 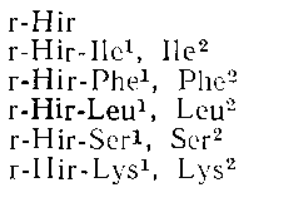 & $\begin{array}{r}0,231 \\
0,099 \\
0,238 \\
9,910 \\
175,000 \\
152,000\end{array}$ & 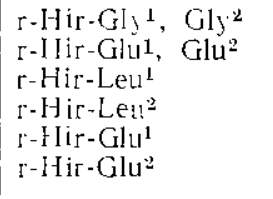 & $\begin{array}{r}094,000 \\
67000,000 \\
0,235 \\
10,300 \\
295,000 \\
248,000\end{array}$ \\
\hline
\end{tabular}


тромбина, которые влияют на его активный центр. Отмечается низкая коонеративность при одновременном использованин фрагмснтов $1 .-52$ и 53--65: совместно они ингибируют тромбин в $10^{5}$ раз хуже, чем исходный рекомбинаптный гирудин. Показано, что фрагмснт 53-65 защищает тромбин от расщепления его трипсияом, а фрагмент $1-52-$ טт расцепления панкреатической эластазой. Эти данные по,твержікют прсдположсние о том. что гирудин связывастся с выступающей на поверхности тромбина пстлей, которая имеет отношенце к его аниоп-сиязывающему участку.

Интерссыые исследования проводили по модификации в гирудине остатков тирознна в положениях 3 и 63 полипептидної цепи [31]. Если дссунфирование Туг-63 в рекомбинантом гируднне снижает его актиіность по сравнению с прнродным в 6-10 раз, то нитрование или йодирование Туг-63 восстанавливает ее почти до уровня природного ингибитора. О,ннако нитрование Tyг-3, наоборот, в $4-5$ раз снижает активлость. Возможно, механизм изменения активности вкиючает уменьшсние величиы рК гидроксильной группы тирозина в результате введения в его ароматическое ядро таких электроноакцепторных заместителей, как I- или NO,-группы, что прнводит к увеличению отрицательного заряда при нейтральных значениях рН.

В случае Туг-63 это ведет к имитации сульфирования и увеличению сродства к тромбину за счет лучшего связывания с анион-связываюшим участком. Олнако при модификации Туг-3 снижение pK ОН-группы увеличивает полярность остатка, что может дестабилизировать его взанмодействне с аполярным связываюцим участком вблизи активного центра фермента. Такоӥ мехализм подтверждаслся тем, что замсна высококонсервативного остатка Туг-3 на Phe или Trp почти в 2 раза увеличнзает сродство к тромбину, а их йодирование или нитрование ведет к еше больпему увеличению сродства (что, возможно, сзязано с повыненисм гидрофобпости остатков в положении 3 полипептидной цепи гирудина). Получелные в работе [31] результаты подтверждают важност, N- п С-концевых сегментов для взаимодействия с ферментом.

Lо сих пор мы рассматрнвали изучение образования гируднн-тромбинового комплекса с использованием различных модифнкаций моле-

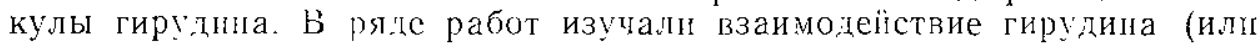
его (рагментов) с мо:ифицированным тромбнном, что также явилось источником пенной информации.

Ввнду того, что большое зичение в ингибированин тромбина придаваяось наличию в гирудине нескольких кислых остатков в его С-копцевой части, прелполагалось, тто они цолжны еступать в ионныс взаимодейстын с основными ампнокислотамп, которые расположены на поверхности молскулы тромбина. Исхоня из этого Чэнг с соавт. [32] изучилг влияние на связывание гирудна с. тромбином модификаций

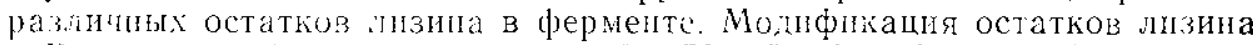
в В-цепі тромбнна в попоженнях 21,52, 65, 106, 107 пли 154 вызгала снижелие сродсва к гирудину в среднем па $20 \%$. Oти результаты подтверлдают, что указанные остатки лизина в ферменте уиаствуот в связиванин с гирунином и расиоложены внутри или рядом с пентром связывания в тромбине.

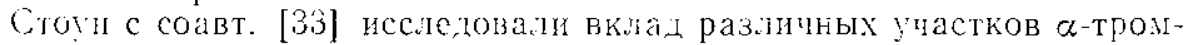
бнла в связывание. Использовали разиичные модификации тромбила как в районе активного центра (диизопропитфторфосфат или иеобра-

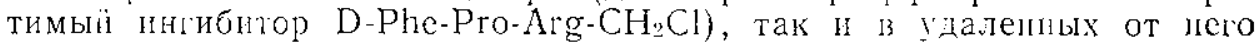

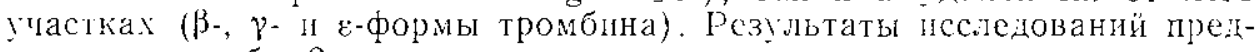
сіавиены в таб̆л. 2.

Как внцио из табл. 2, для связывания гирудина важно окружение активноо центра. Хлорметилкетон тринелтия, закрывающий аполярнай связывающий центр, ингибрует связывание с гирудином в 1000 раз сильлее, чем диизопролильторфосфат, который модифицирует остаток серниа в каталитичсском центрс. Интсресны рсзультаты по ингибирования протсолитическими формами тромбнна: в-тромбин име- 
ет разрыв в В-цепи па участке $154-155, \gamma$-тромбин - выщепление в В-цели двух пептидов - 63-73 и 124-154, а $\beta$-тромбин - выщепление только фрагмента 63--73 [1]. Соответственио количеству повреждений в В-цепи тромбина изменяется и его сродство $\mathrm{k}$ гирудину, особенно важен участок 63-73. Поэтому авторы делают вывод о его большом значепии гля образования ионных взаимодействий с гирудином.

Интересная информация о природе взаимодействия гирудина с тромбином была также получена при использовании иммунологических методов. Ноэ с соавт. [34] получили поликлональғые антитела к синтетниескому пептиду H-Arg-Ile-GlyLys-His-Ser-Arg-Tyr - Glu-Arg - OH, соответствующему выщепляемому фрагменту В-цепи $62-73$ в $\beta$ - и $\gamma$ формах. Антитела хорошо связывались как с $\alpha$-тромбином, так и с его бромциановым фрагментом, содержащим последовательность $62-73$, конкурентно ингибирован1и связывапис гирұднна в пределах концентрациі от 0 до 43 нмоль/л и не влияIIи на ги,тролиз тромбином хромо-

Тт а б бли ц а 2

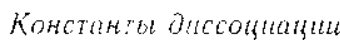

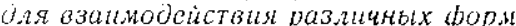
тронбина с аирудинон [33]

\begin{tabular}{|c|c|}
\hline Форма тромбина & $\begin{array}{c}\text { Константа дис- } \\
\text { соннашни } \\
\left(K_{d}\right), \text { м }(\lambda \mathrm{b} / \Omega\end{array}$ \\
\hline $\begin{array}{c}\alpha \\
\beta \\
\gamma \\
\varepsilon \\
\text { Rursonponisidropфocфar } \\
\text { D-Phe-Pro-Arg-CH }\end{array}$ & $\begin{array}{r}22 \cdot 10^{-15} \\
(2,9 \pm 0,2) \cdot 10^{-12} \\
(19 \pm 1) \cdot 10^{-9} \\
(56 \pm 7) \cdot 10^{-15} \\
(26 \pm 6) \cdot 10^{-12} \\
(19 \pm 2) \cdot 10^{-9}\end{array}$ \\
\hline
\end{tabular}
генного субстрата. Кроме того, они ингибировали отщепление фибринопептидов $\mathrm{A}$ от двух $\mathrm{A} \alpha$-цспей фибриногена с $K_{i}=11,7 \pm 4$ пмоль/л. На основании этих данных делается вывод о том, что антитела экрапируют алнон-связывающий участок тромбина от его взаимодействия $c$ I'ирудином.

1Цлеппи с соавт. [35] полунили набор моноклональных антитсл к природному гирудину, рекомбинантному гирудину и двум его синтетичсским фрагментам 40-65 и 52-65. Только моноклональные антитела к рекомбинантному гирудину показали высокое сродство к гирудину. Эпитопный анализ показал, что все связывающие домены антипентидных антител расположены вблизи С-концевой части молекулы гируднна, так как связь между остатками Glu61 и Glu62 защищена от расцепления стафилококковой: протеазой. Антитела к рекомбинантному гшрудину предотвращали расщеплмие связсй Glu43-Gly44 стафилококковой протеазой и Lys ${ }^{47}-$ Pro's $^{\prime \prime}$ лизил-эндопептидазой. Предполагается, что этот эпитоп вовлечен в связывание с тромбином.

Слелующий раздел посвящен изучснию взаимодействия гирудина и тромбина с привлечением мстодов химического синтеза пептидов.

Химические методы. Биохимическне методы нсследования гирудинтромбинового взаимодействия дали много ценной информащии, позволяюнцей иредполаган механизмы этого процесса. Дополнительная информация о взаимодействии фрагментов гирудина разной величины с тромбином была получена благодаря использованию в исследованиях больпого количества синтетических пептидов.

Авторы работы [36] изучали взаимодействие синтетического фрагмента гирудина 45-65, содержащего несульфированный тирозин и ацетиялированный по концевой аминогруппе, с тромбином. Он способен ннгибировать свертывающую активность тромбина, однако активный центр фермента при этом не затрагивает, так как действие пептида не влияет на гидролиз хромогсіного субстрата. Пептид связывается с едннственным центром в тромбине с константой ассоциации $10^{5}$ моль ${ }^{-1} / л^{-1}$, что лишь на порядок меньше, чем константа взаимодействия тромбина с гнрудином. Это свидетельствует о том, что фрагмент 45-65 содержит связывающий домен, узнаваемый ферментом, однако не связывается с его активным центром.

В следуюпей работе этих авторов [3] исследовалось взаимодействие тромбина с серией из 20 синтетических аналогов ссгмента 55-65 гирудниа. В минимальном участке, необходимом для эффективного 
ингибирования (сегмент 56-64) свертывающей активюости тромбина, остатки Phe-56, Glu-57, Ile-59, Pro-60 и Løu-64 оказались чувствительными к заменам другими аминокислотами. Предполагается, что они необхо,цимы ,ұл прямого взаимодействия с ферментом или для поддержания нужной конформации ингибитора. ПЈедполагается также возможиость образования на этом участке амфифильной $\alpha$-спирали, о чем мы упоминали рансе (см. рис. 3). Обрашаст на себя внимание важность некоторых гилрофобных остатков, а также тот неожиланный факт, что пз тетырех остатков глутаминовой кисліоты только один (Glu-57) оказался необхо;имым для эффсктивного ингибирования. Кроме того,
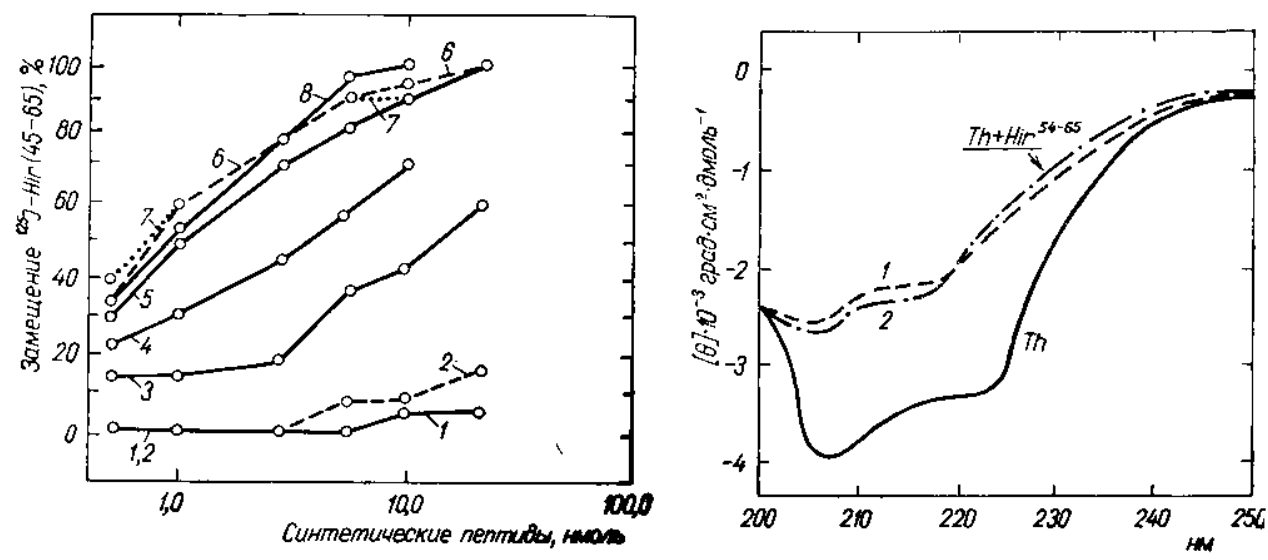

Рис. 6. Замещение ${ }^{125}$ І-меqенного фрагмента гирудина 45-65 с тромбин-сефарозы синтетическимп пептидами. Фрагменты гирудина: $1-58-65 ; 2-57-65 ; 3-56-65 ; 4-$ $55-65 ; 5-54-65 ; 6-52-65 ; 7-50-65 ; 8-45-65[38]$

Рис. 7. Спектры КД тромбина и его комплекса с фрагментом гирудина 54-65. Добавки фрагмента гирудина: $1-2 ; 2-1$ нмоль [38]

если сульфирование остатка Туг-63 в пептиде приводит к 10-кратному увеличению его ингибирующей способности, то замена его Tyr-63 п्а остаток глутаминовой кислоты снижает ее в 4 раза.

Как считают авторы приведенной работы, на основании сравиения последовательностей С-концевой части гирудина и фибринопептидов $\mathrm{A}$ и В нельзя сделать вывод о том, что гирудин и фибриноген связываются с одним и тем же участком тромбина и что, если они и используют для связывания некий общий участок, модсли взаимодействия с ним гиру: (ина и фнбриногена могут быть различными.

Оуэн с соавт. [37] продолжили изучение синтетических фрагментов сегмента 54-65 для определения оптимальных остатков в поножениях 54 и 56 для связывания. Оказалось, что минимально необходимой последовательностью является 56-64, содержашая в положении 56 $L$-аминокислоту. Замена Phe-56 на Tyr не приводит к изменению ингибирующей активности, в то время как замена его на $n$-хлорфенилалапин или фенилглицин - к ее спижению. Удаление аминогруппы концевого остатка Asp-55 (путем замены его янтарной кислотой) также ведет к возрастанию активности. Высокая чувствительность аминокислоты в положенин 56 пептидной цепи гирудина к модификациям свидетельствует о ее важности для взаимодействия с тромбином.

Мао с соавт. [38] исследовали взаимодействие серии синтетических фрагментов С-концевого участка гирудина $(45-65,50-65,52-65$, $54-65,55-65,56-65,57-65$ и 58-65) методом гель-фильтрации при высоком , тавлении, а также по их способности вытеснять меченный I $^{125}$ гирутин из его комплекса с иммобилизированным тромбином (рис. 6). Сродство фрагментов к тромбину падало при замене Phe-56 на его $D$-изомер, Glu или Leu.

Проводилось также изучение серин синтетических пептидов, отвечающих послсдовательности 45-65 гирудина [39], с целью определе- 
иия минимальіой длины эгого фрагмента, обладающего антикоагулянт нымн свойствами, анализа роли сульфированного Туг-63 и оценки вклала участка 45-64 в связывание с тромбином. Этот фрагмент был актнвным в завнсимости от концсптрации гри измерении тромбопластинового времени нормальной плазмы человека, но не проявил заметной активности при гитролизе хромогенного субстрата. Минимальная :ллнна пептпја с максимальной антнкоагулянтной активностью - 12 остатков (53-64). ІІри обработке этого пептида серной кислотой в диметилформамиде в присутствии дициклогексилкарбодиимида получили анаэог, солержащий сульфнрованный Туг-63, который был в 10 раз активнее нссульфнрованного пептп; $53-64$, но в 50 раз менее активен, чем лрнродный гируднн.

Ввиду того, что сульфированный фрагмент по ингибирующей аћтнвности мало отиичастя от гирудина, предполагается, что взаимодеїствне гиру:цина с некаталитнческим центром тромбнна является преобпалалющ в ингибировании физиологической активности фермента. Показано также, что сульфированный фрагмент 53-64 проявляст в 10 раз меньњее сродство к тромбнну быка, чем к тромбину человека. Это можно объяспить отсутствием в В-цепи тромбниа быка сайта $\gamma$-расщепления (Lys-149). Обсуждается вопрос о структуре участка гирудина, ответственного за связывание со специфическим «карманом» активного центра фсрмента: отрицается возможность связывання участка, содержащего основную аминокислоту, так как в гомологичных гиру,цинах нет пг одного консервативного остатка лизина и отсутствуст аргинин.

Для вылснення роли разиичных участков гируднна в связывании были синтезированы [40] фрагменты, содержащие от 15 до 51 амннокислотного остатка: $1-15,15-42,15-65,29-65$ и $40-65$. С-Концевой фрагмент 40-65 ингибнровал только свертываюшуул активность фермента, пептид 15-65 эффективно ингибировал расщепленис как фрибрнногена, так и хромогенного субстрата, что свидетельствуст о важном вк.la: це центрального кора для связывання с активным центром фермента. Эти рсзультаты согласуются с ранее полученными ланными [33] том, что моцифнкация гистидином активного цснтра тромбина снижаст сго сродство к гирудину в $10^{6}$ раз. N-Концевой фрагмент $1-15$ ингибировал гидролиз субстрата с такой же эффективностью, как аналог $15-$ 65, но в качестве ингибнтора расщепления фибриногена он оказался более чем в 100 раз менее эффективным. Это доказывает, что N-концевая часть молекулы гирудина взанмодействует только с активным центром (нли анолярным связывающим участком вблизи него) тромбина.

В заключение этого раздела приведем очень интересную работу [41] по использованно синтетнческого фрагмента 54-64 гирудина для специфической метки остатка Lys-149 в тромбине. С этой целью синтетический пептид алкилировали по аминогруппе бифункциональным реагентом 1, 5-дифтор-2, 4-динитробензолом (DNDFB), а затем суиьфировали по остатку Tyr-63, причем таким образом он метилсі ${ }^{35} \mathrm{~S}:$

$$
\text { DNFB-Gly }{ }^{54-A s p-P h e-G l u-G l u-I l e-P r o-G l u-G l u-T y r-L e u-O H}{ }^{64}
$$

При обработке тромбина избытком меченого пептида динитрофторбензильная группа пентида реагировала с $\varepsilon$-амнногруппой Lys-149 фермента. Образование ковалентной связи пептида с ферментом было доказано хроматографически путем нзмерения радиоактивности фермента после обработки меченым пептидом. Специфичность ковалентного связывания доказывалась тем, џто при добавлении в реакционную среil большого нзбытка необработанного DNDFB радиоактивного фрагмснта 54-64 выход комплекса значительно снижался за счет конкуренции за связыванне со специфическим участком тромбина.

IІутем ферментативного расщепления комплекса и разделсния фparмcнтов было показано, что пептид связывался с остатком Lys-149 
в тромбнне, который, таким образом, находится рядом с участком связывания гирудина. Это является хорошим экспериментальным доказате.тьством того, что гирудин связывается с ферментом в районе анионсвязываюшего сайта. Қроме того, это позволило на основании данных рентгеностуктурного анализа тромбина определить, что анион-связывающий сайт расположен на расстоянии $1,8-2,0$ нм от каталитического центра фермента.

По:цоця итоги результатов изучения образования гирудин-тромбинового комплекса биохимическими и химичсскими методами (а эта огромная работа была проведена в основном за короткий период с 1987 по 1990 Го, $)$, можно отметить следующее.

1. Показано, что гирудин взаимодействует с тромбином в двух осповных сайтах-С-концевой домен, по-вицимому, взаимодействует с
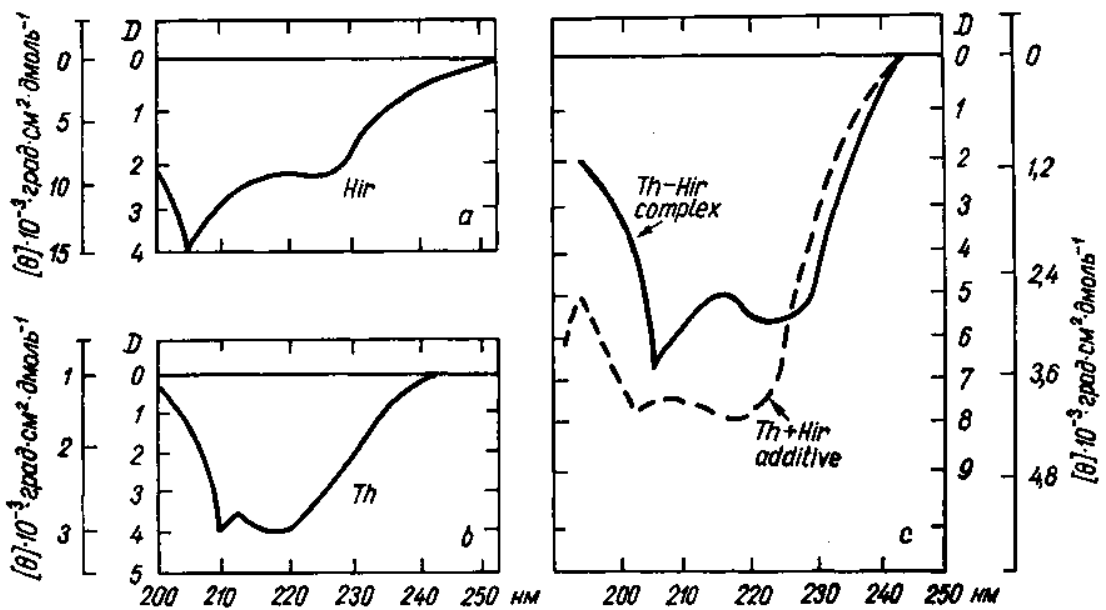

Рис. 8. Спектры КД гирудина (a), тромбнна (b) и их комплекса (c) [42]

аниог-связывающим сайтом тромбина и это вносит большой вклад в энергию связывания; N-концевой фрагмент и центральный кор взаимодействуют с аполярным связывающим участком вбіизи активного центра фермента, однако, скорее всего, связывающий «карман» тромбнна в этом взаимодействии участия не принимает.

2. Установлено эффективщое ингибирование свертывающей активности тромбина небольшим фрагментом 54-64 гирудина, что открывает пути для создания хороших синтетических ингибиторов тромбина нового типа. Однако, еслй результаты этих исследований прояснили картину взаимодействкя тромбина с гирудином в общих чертах, то окончательно мехапизм этого процесса был установлен с помощью изучепия комплекса гирудин - тромбин физическими методами.

Физические методы. Изучение строения комплекса гирудина с тромбином физическими методами также было проведено за короткий срок-с 1987 по 1990 гг. и привело к окончательному решению проблемы.

В уже упоминавшейся работе Мао с соавт. [38] изучались спектры кругового дихронзма (ҚД) тромбина в присутствии С-концевого синтетического пептида 54-65 и укороченного фрагмента $57-65$. Спектры снимали в присутствии пептидов и без них (рис. 7). Структура тромбина в присутствии фрагмента 54-65 более беспорядочна, что свидетельствует о конформационных изменениях, происходящих при образовании комплекса, однако фрагмент $57-65$, плохо связывающийся с тромбином, не влияет на спектр ҚД тромбина. Пептиды брали в такой концентрации, чтобы отсутствовало их собственное дихроическое поглощение. Предполагается, что наблюдаемое изменение конформации тромбина может быть причиной снижения свертывающсй и других активностей фермента. 
Конно с соавт. провели болсе тщательное исследование спектров КД комплекса [42]. Они показали, что кривые КД комплекса гирудин тромбин (рис. 8) отличаются как от спектра КД самого гирудина или тромбина, так и от их суммарного спектра. Это отклонение от аддитивности особенно велико в области от 210 до 225 нм, что указывает иа нзменение вторичных структур обоих белков при образовании ими комплскса. В процессе титрования тромбина гирудином спектральное отклонение от аддитивности имеет сигмоидальный характер, что по.фтвержглает кооперативность процесса связывания. Гель-фильтрация смесп тромбина и гируднна не показала иного состава комплексов, чем i : 1, однако гель-фильтрация свободного гирудина выявила, что он существует в форме ассоциированных молекул разного состава. Отсюда следует, что кооперативный характер процесса обусловлсн взаимодействнем тромбина с множественной формой гирудина, причсм на второй стадии множествениый комплекс диссоциирует в тип 1:1. Это приводит h заметным конформационным изменениям и значительному изменению связывания. что и регистрируется методом КД.

bonьuой ннтерес представляет изучсние в этой работе спектров КД компјексов гирудина с различпыми молификациями тромбнна (таб̆. 3). Регистрировали отклонение эллиптичности от адднтивности прн 222 нм, чем и характеризовалось связывание. Қак видно из табл. 3, наименине отклонение $(0--5 \%)$ наблюдалось в случае ингибироваиия тромбина необратимым ингибитором, а при использовании $\gamma$-тромбина оно составило $30--40 \%$ (для $\alpha$-формы отклонение условно принято за $100 \%$ ). Так как отклонение от аддитивности уменьпалось с ухудшением связывания, сделан вывод о вауности как активного центра II его окружения, так и основного участка В-цепи тромбина $63-74$ (огсутствюшего в $\gamma$-форме) для связывания.

Cлелует отметить, что мето.1 КД является относительно малоинформативным для изучения вторичной структуры белков, поэтому знаџитепюю более ценная информация получена при использовании метоIa ЯМР в растворе. Ни с соавт. [43] исследовали взаимодействие тромбина с синтетичсскими фрагмснтами гирудина $52-65$ и Ас-55-65 мето.10м одномерного in двухмсрного ЯМР. Установлсно наличие $\leftrightarrow$-спира.ти на участке гирудина 61-65. Фрагмент 55-65 дает в комплексс с тромбнном хорошо разренаемую структуру. Это отчасти верно и для пептин 56--65, так как наблюдался средний и дальний перенос поляризащиг, обусловленный ядерным эффектом Оверхаузера (transferred NOE), мсклу протонами остова полипептидной цепи и боковых остатков аминокислот. Отмечается, что структура сегмента 55-65 довольно амфифильн. т. е. олна сторопа ее полярна и заряжена, а другая гидрофобла. С-Қонцсзые пептиды - фрагменты гирудина - не взаиnoдействуют с каталитнеским центром фермента. Остатки глутамино-

Т а бли и а а 3

Отклонение от адынтивности спектров КД гирудин-тромйинового romnerea [42]

\begin{tabular}{|c|c|}
\hline $\begin{array}{c}\text { Состав исследуемых смесей } \\
\text { компонентов }\end{array}$ & $\begin{array}{c}\text { Отклонение } \\
\text { эллиптичности } \\
\text { от аддитивнос- } \\
\text { ти, \% }\end{array}$ \\
\hline 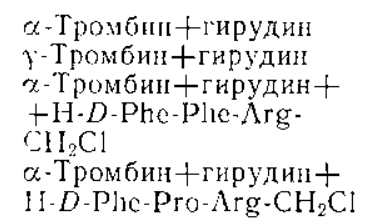 & $\begin{array}{l}100 \\
30-40\end{array}$ \\
\hline
\end{tabular}

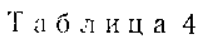

Cравнательная способность

К инальбированию тронбина различных фрагментов физиологтчески важных белков гемостаза [54]

\begin{tabular}{|c|c|}
\hline Фрагменты белков & $\begin{array}{c}\text { Эффективность } \\
\text { ингибирования } \\
\text { свертывания } \\
\left(1 \mathrm{C}_{\text {во }}\right) \\
\text { мкмоль } / \pi\end{array}$ \\
\hline
\end{tabular}

Кофактор II гепарина человека $(54-75)$

Tо же $(49-75)$

$\mathrm{B}_{\beta}$ - цепь фибриногена

(410-427)

Тромбомодулин (426-444)

Гирудин десульфированный

Гирудин природиый $(54-65)$
38

28

130

140

1,3 
вой кислоты в положениях 58,61 и 62 обращены в сторону растворителя, чсм можно объяснить их неучастие в связывании, как указывалось ранеe [3].

Однако Glu-57 необходима для взаимодействия из-за сближенности с гидрофобным ядром молекулы и поэтому может принимать участие в ионном взаимодействии. Эти структурные особенности реализуются за счет изменення направления цепи возле остатков Glu-57 и Glu-58 посредством вытягивания структуры, включая остатки Ile-59 н Pro-60, а также поворотом нскаженной $\alpha$-спнралің из остатков от Glu-(j): ‘о Glu-65 на полтора оборота.

Что нового в понимании механизмов взаимодействия гирудина с тромбином дали этн исследования? Во-первых, они подтверцили неструктурированность С-концевой части гирудина в отсутствие тромбина, что согласуется с более ранними данными [19]. Во-вторых, подтверждено образование амфифильюго кластера сегментом 52-65, что очень, похожс на прсдсказанную ранее амфифильную спираль (см. рнс. 3), которая может образоваться в результате взаимодействня с тромбином.

O.дако решаюшую роль в физических исследованиях сыграги работы по прямому изучению строения комплекса гируднн - тромбин мето,дом рентгеноструктурного анализа, опубликовалные почти одновременно $[44,45]$. На основании цанных проведенного анализа кристалиов комплекса было получено четкое доказательство того, что гирудин ингибрует тромбин по неизвестному ранее механизму ингибнрования сериновых протеаз: в отличие от других известных ингибиторов специфичность гирудина обусловлена не взаимодействием со специфитеским связывающим «карманом» фермента, а, скорсе, участками, расположенными как вблизи активного центра, так и на некотором удалении от него. В гирудине имсется $\mathrm{N}$-концевой глобулярный домен и протяженный $(3,9$ нм) С-концевой цомен. С-Қопцевой сегмсіт 48-65 закручсн вокруг молекулы тромбина вцоль предполагаемого анион-связывающего сайта и связан с ним электростатическими силами, в то время как пять последних остатков образуют спиральную петлю, которая можст образовывать несколько гидрофобных контактов с ферментом.

Анион-связывающй участок тромбина представляет собой длинную шель, вытянутую от впадины активного центра тромбипа и закрытую петлями $35-59$ и 70-80 в В-цени. Очень интересные результаты получены относительно механизма взаимодействия гирудина с областью активного центра фермента: гирудин связывается с участком вблизи активного центра своими тремя $\mathrm{N}$-копцевыми остатками Val-1, Val-2 и Туг-3 (как было предсказано в работах, приводимых в предыдущих разделах!), причем Val-1 занимает подцентр $S_{2}$, а Туг-3 подцентр $S_{3}$ в тромбине [9], т. е. аполярный связывающий участок.

Iо ;анным рентгенструктурного анализа, 27 из 65 остатков гнpуднна сближены в пространстве на расстоянии менее 0,4 нм с тромбниом (10 нонных пар и 23 водородные связи), чем можно объяснить высокую аффинность и специфичность гирудина. Предплагается, ито $\mathrm{N}$-концевая анннокислота образует водородную связь с гидроксилом серина каталитического центра тромбина, но специфический «карман» фермента во взаимодействии с ингибитором участия не принимает. Схема взаимодействия гирудина с тромбином изображена на рис. 9.

Перспективы практического использования результатов исследований. Выше отмечалось, что основной целью почти 100-летнего изучения ингибнтора гирудина было использование его в киникс в качестве антикоагулянта и создание новых препаратов, механизм действия которых основан на тех же принципах, что и ингибирование тромбина гирудином. Исследования на лабораторных животиых $[46,47]$ и человеке $[48,49]$ показали, что гирудин может быть использован в медицинской практике в кацестве высокоселективного и эффективного антикоагулянтного препарата ввицу сго высокого сродства к тромбину, очень низкой 
антигенности и возможности быстрого выведения из кровяного русла (время его полужизни в организме около 1 ч). Поэтому гирудин может прнменяться для лечення тромбозов наряду с широко используемым в клиникс сстествениым ингибитором, содержацимся в организме, гепарнном $[46,49]$.

Возникает вопрос, лочему до сих пор использование гирудина в клинике не пошло :альше экспериментальных псследований, если его

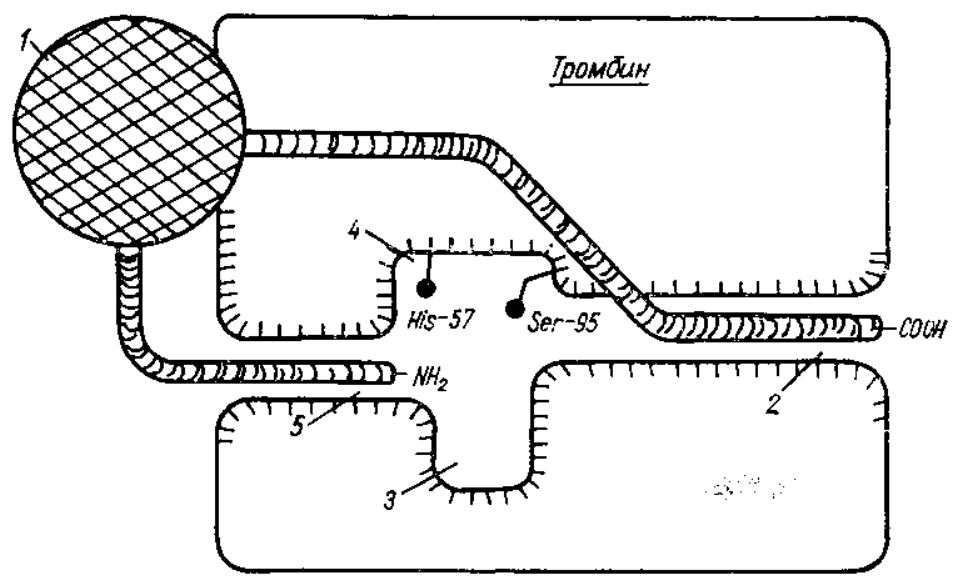

Рнс, 9. Схематнческая диаграмма гирудиш-тромбинового комплекса по данным рентгеноструктурного ала.тиза: 1 - центральный кор гирудина; 2 - фибриноген-связываюная цсль в тромбине; 3 - первнтый связывающий «карман» тромбина; 4 - каталитиескнї целтр фермсіта; 5- аполярный связывающий участок тромбнна [44]

выделснис из природного источника (медицинских пиявок) как-будто не составляет большой проблемы? По лриблизительным оценкам Марк13ар):та [2], ежегодно дыя научных исследований требуется 50 тыс. пиянок, однако их количество в природе ограниченпо, и тому жс недавно они были занесены в список исчезаюцих видов! Значит, нужны другие источники гирудина. В этом большую помощь могут оказать биотехнологические ме. тоды лолучения рекомбинантного ингибитора. Кроме работ в этом паправлении, упомянутых нами ранее, можно указать еще несколько публикаций [50-53].
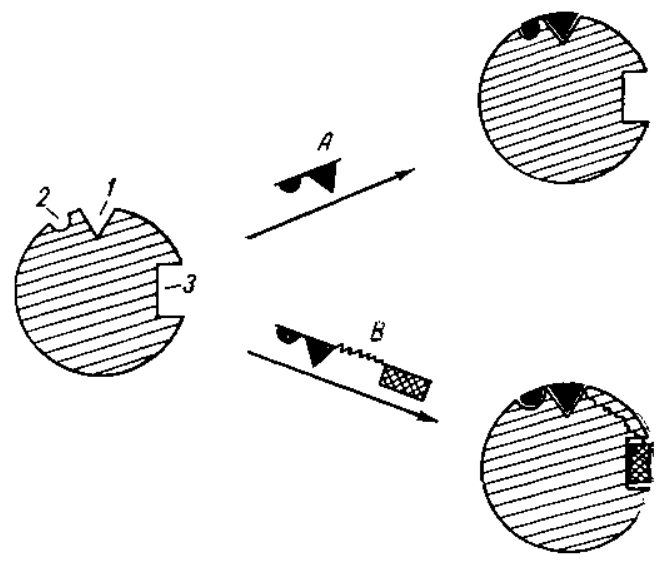

Pис. 10. Схема ингибирования тромби на пептидом $D$-Phe-Pro-Arg-Pro-Gly $(a)$ и гируліогами (б) [56]

По-видимому, в терапевтических целях мыжно использовать пс только гирудин, но и его небольшие синтетичсские фрагменты. Напримср, Хортни с соавт. [54] приводят свсдения о сравнитсльной антисвертывающей активности фрагментов различиях природиы субстратоз а пнгибиторов тромбнна, имеющих анионную приро;у н, вероятно, взаимодействующих с анион-связывающим сайтом фермента (үабл. 4). Из таблицы вилно, что синтетичсский фрагмент гирудина $54-65$ (и особснно сго сульфированиый аналог) является гораздо лучшим ингибитором, чем все приведенные пептиды. Это особенно важно, если принять во внимание, что Хортии [55] получнл патент на ислользование в качестве антитромбинового лрепарата 22-членного синтетического пелтида, соответствующего лоследовательности $54-75$ (с заменой Ser-68 на Ala) кофактора II гепарина человека (см. табл. 4). 
В заключение обзора следует рассмотреть очснь важную и перспектнвшую работу по созданию гирудиноподобных ингибиторов тромбнна - «рирулогов» [56]. Целью се было получение эффективного обратимого ингибитора тромбина на оспове изученных механизмов ингибирования его гирудином. Для взанмодействия с анион-связывающим сайтом тромбина авторы использовали синтетичсский пептид - фрагмeliт 54-64 гирудина, а для связывания с активным центром фермента-- известный синтетический ингибнтор D-Phe-Pro-Arg-Pro-Gly, которыс связали друг с другом «мостиком»из остатков глицнна (рис. 10). Важным в этої работе было то, что авторы исло: ьзовали информацию о расстолнии мсж,т! әтимн : вумя связывающима центрами в тромбине $18-2,0$ HM (тай. 5 ).

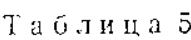

Константы инаибирования аиоролиза тронбином п-нитроанилида D-гексагиоротирозия-аланил-ареинина гирулогани [56]

\begin{tabular}{|c|c|c|}
\hline Сасдинение & Аминокислотная последювательнось & $\begin{array}{c}K_{i}, \\
\text { нмиль/л }\end{array}$ \\
\hline 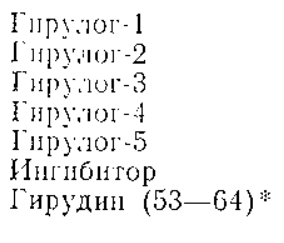 & 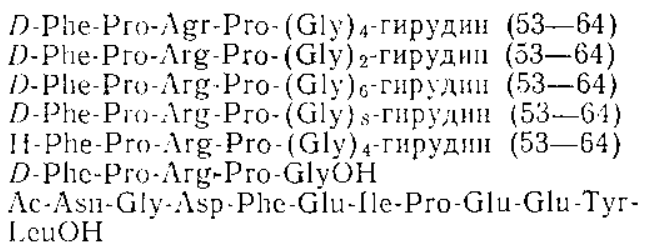 & $\begin{array}{c}2,3 \\
64,5 \\
3,0 \\
2,6 \\
156,0 \\
>2 \cdot 10^{3} \\
>2 \cdot 10^{3}\end{array}$ \\
\hline
\end{tabular}

* Синтетисскиї ррагмент 53--64 гирудина ускорлет гидролиз хромогсиног субстрата.

113 табл. 5 видно, что для эффективного ингибирования тромбина , достаточно, чтобы мостик был ностроен нз четырех остатков Глицина. Этот синтетнческий пептид проявляет антнкоагулянтную активность, сраниниую с активностью гиру дина и в 100 раз (!) превосходяную актизиость сульфированного фрагмента 53-64. На первыӥ взгляп, больmiм прсимупеством гирудина перед гирулогани явіястся то, что он пе взанмодействует со специфическим «карманом» активного центра тромблна, т. е, в принщипе (в отлитне от гирулогов) не может ингибировать 'цугие тринсиноподобные ферменты системы свсртывания крови. Сле-

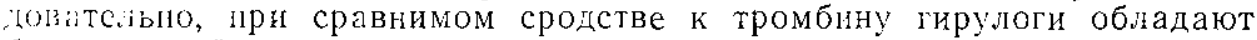
болсе пнзкой селектнвностью, чем гирудин, что является очень важным фактором при создании терапевтического препарата.

Однако опыты по ингибированию гндролиза хромогенного субстрата фактором $X_{a}$, плазмином і трипсином показали, что эти ферменты iе нигибировались гирулогом-1 даже в концентрациях, в 1000 раз превынающих таковые указанных ферментов. Таким образом, гирулоги об.талалот достаточно высокой селективностью к тромбину, чтобы sн11ться примсром нового класса его бивалентных ингибиторов.

Автор выражает благодарность В. К. Кибиреву за обсуждение руиописи обзора и ценные замечания и $\Lambda$. $\Lambda$. Серейской - за предоставтенне некоторых оригинальных работ по теме обзора.

Ре $з$ юме. Розглянуто біохіміні, хіміниі та фізичні підходи до вивчения будови гірудина i механізму пригнічения ім тромбіна. Результати цих досліджен відкривають щ.лях до створення синтетичиих інгібіторів тромбіна нового типу.

Summary. Biochemical, chemical and physical methods for study of hirudin-thrombin bounding mechanisms are reviewed. Perspectives of the clinical usage of recombinant hi. rudin and its small synthetic iragments are obsurved. The possibility for designing of wovel drugs based on the studied hirudin-thrombin interaction mechanisms is shown on example of syntheic hirudin-like inhibitors «hirulogs». 


\section{СПИСОК ЛНТЕРАТУРЫ}

1. Bioregulatory functions of thrombin/Eds D. A. Walz cl al.-New York: Acad. Sci., $1986 .-450 \mathrm{p}$.

2. Markwardt $F$. Pharmacology of hirudin: one hundred years aiter the first report of the anticoagnlaut agent in medical lecches// Biomed. and biochins. acta.- 1985.44, N 7/8.-P. 1007-1013.

3. Anticoagulant pepticles: nature of the interaction of the C-terminal region of hirtidin Wifl a noncatalytic binding site on thrombin/J. L. Krstenansky, T. J. Owen, M. T. Yates, S. J. T. Mao//J. Med. Client. - 1987.-30, N 7.-P. 1688-1691.

1. Markwat $f$. Die Isolierung und Chemische Charakterisiernng des Hirudins// Hoppe-Seyler"s Z. Physiol. Chem.-1967.-308. N 4.-S. 147-156.

5. Fonton $J . W . ~ I I$. Thrombin specificity//Am. N. Y. Acad. Sci. $-1981 .-370 .-$ P. $468-495$

6. Серсбряный $C$. Б. Тромбин: его строение и особенности катализа // Биолимия животих п человека.-- 1982.- Вып. 6-C. $14-26$.

7. Crptrosa C. M. Структурно-функциональные особенности тромбнна // Там же. $\rightarrow$ C. $26-38$.

8. Fenton J. W. II, Sonder S. A. Thrombin active-site regions and functions//Ann. N. Y. Acal. Sci.- 1984.-435.- P. 412-414.

9. Shechter I., Berger A. On the size of the active site in proteases. 1. Papain//Biochem. and Biophys. Res. Communs. - 1967.-27.- P. 157-162.

10. The refined $1,9 \AA$ crystal structure of human $\alpha$-thrombin: interaction with $D$-PhePro-Arg chloromethylketone and significance of the Tyr-Pro-Pro-Trp insertion seg-

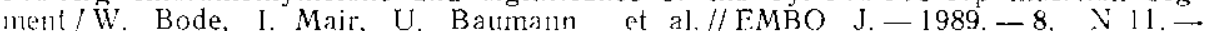
P. $3467-3475$.

11. Humm D.Phe-Pro-Arg-CH$H_{2}-\alpha$-lhrombin crystallization and difraction data/ E. Skrzypezak-Jankun, T. Rydel, A. Tulinsky et al.//J. Mol. Biol. - 1989, - 206, N $4 .-$ P. $755-757$.

12. Catalylic compctence of human $\alpha$ - and $\gamma$-thrombin in the activation of fibrinogen and factor XIII / S. D. Lewis, L. Lorand. J. W. II Fenton, J. A. Shafer// Biochemist. ry.-1987-26, N 24-P. $7597-7603$.

13. The complele amino acid sequence of hirudin. a thrombin specific inlibitor/J. Dendt, H.-P. Müller, U. Seemüller, J.-Y. Chang// FEBS Lett.-1984.-165, N 2.-P. $180-$ 184.

14. Rapit purification and resised amino terminal sequence of hirudin: a smerifis thrombin inlibitor of the Bloodsucking leceh/S. J. T. Man, M. T. Yates, D. T. Blankensip et al.// Anal. Bioclem- 1987.- 161.- P. 514-518.

15. Cloning and expression of a cDNA coding for anticoagulant hirudin from the 3 loodsucking leech, IIrudo medicinalis/R. P. Harvey, L. Degryse, L. Stefani ct al.// Proc. Nat. Acad. Sci. USA - 1986.-83, N 4-P. $1084-1088$.

16. Isolotion and charaterization! of hirudin isoinhibitors and sequance analysis of lifudin P.L / J. Dodt, W. Machieidt, U. Seemïller et al.//Biol. Chem. Hoppe-Sezler.-1986 - 367 , N 6.- P. $803-811$.

17. Chang $J_{+} Y$. The functional domain of hirudin, a thrumbin specific inlubitor//FEBS Lett. - 1983.-164, N 2.- P. 303-313.

18. Point muntations modifying the thrombin inhibiton kineties and antithrombotic artivity in vizo of recombinant hirudin / E. Degryse, M. Aclies, G. Defreyn et al. il Protein Eng.-1989.-- 2, N 6.- P. 459--465.

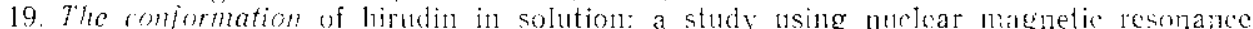
distance geometry and restrained molecular dymamics/G. M. Clore, D. K. Suknuiaran, M. Nigles et a!.//EMBO J.- 1987.- -6, N 2.-P. 529-537.

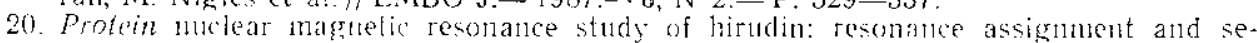
condary stricture/D. K. Sukumaran, G. M. Clore, A. Premss el al./Biotumistr:$1987 .-26$, N 2.... P. 333-338

21. Solution struclure of recombinant hirudin and Lys $47 \rightarrow$ Glu mutant: a mulear mag-

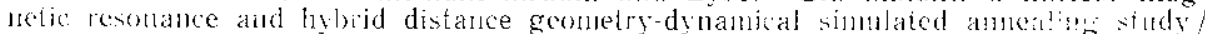
P. J. M. Folkers, (s. M. Clore, P. C. Driscoll el al.// Jbid. $-1989.28, \mathrm{~N} 6$. P. $2601-2617$.

22. Harmyma $H$, Währich $K$. Conformation of recombinant desulfatohirudin in aqueons: solution determined by nuklear magnetic resonance// Ibid - $\mathrm{N} 10-\mathrm{P} .1301-4312$

23. Tetrin $C_{\text {., }}$ De La liosa $P$. lutisz $M$. Effect des modifications chimiques de l'hirudine sut son action inhibitrice de l'artivite enzymatique de lis thrombine/i Bull. Soc. Chinl. Biol.-1967.-49, 12.-P. 1837-1843

24. Stom, S. R., Dennis S., Jofstinge J. Quantitative evaluation of the contribution of ionic interactions to the formation of the thrombin-hirudin complex// Biochemistry. $1989 . \cdots 28, N 17$. P. $6857-$ rixti3.

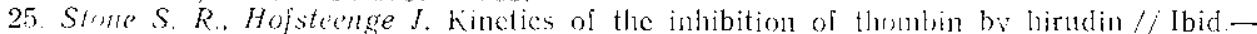
$1980-25$ i 16 - P . $4622-4628$

26. Dodt $I .$, Konler S., Baici $A$. Interaction of site specific hisudin variants with $\alpha$ 1]umbia// FEBS Lett - 1988. - 229, N 1... P. 87-90

27. Usc of sitc-clirected mutagenesis to investigate the basis for the specificity of hirudir / P. J. Braun, S. Dennis, J. Hofsteenge, S. R. Stone// Biochemistry.-- 1988.-27, N $17 . \ldots-$ P. $6517-6522$.

28. Confribution of the N-teminal region of hirudin to its interastion with thrombin/ 1. Nallase, S. Dentis, J. IIofsteenge, S. R. Stone // Ibiri. - 1989. - 28, N 26.P. $10079 \cdot 10081$ 
29. Distinct binding sites of $\mathrm{Ala}^{48}-\mathrm{hirudin} 1^{-47}$ and $\mathrm{Nla}{ }^{48}$-hirudin ${ }^{48-65}$ on $\alpha$-thrombin $/$ J. Dodt, S. Köhler, T. Schmitz, B. Wilheln!//J. Biol. Chem. $-1990-265, \mathrm{~N} 2$. P. $713-718$.

30. Use of fragments of hirudin to investigate thrombin-hirudin interaction/S. Dennis, A. Wallace, J. Hofsteenge, S. R. Stone// Eur. J. Biochenl - 1990.-188, N 1.P. $61-66$.

31. Winant $R$ G Lazar I $B$ Johnson $P$. Chemical modifications and amino acid substitutions in recombinant hirudin that increase hirudin-thrombin affinity// Biochemistry - 1991-30, N 5. - P. 1271-1277

32. Charg J.-Y. The hirudin-binding site of human $\alpha$-thrombin // J Biol. Chem.-1989.-. $264, N 13 .-$ P. $7141-7146$.

33. Stone S. R., Braun P. J., Hofsteenge J. Identification of regions of $\alpha$-thrombin involved in its interaction with hirudis//Biochemstry. - 1987.-26, N 15. - P. 4617 - 4624.

34. The use of scquence-specific antibodies to identify a secondary binding site in thrombin / G. Noe, J. Hofsteenge, G. Rovelli, S. R. Stone// J. Biol. Chem. - 1988.-263, N 24.- P. 11729-11735.

35. Preparation of monoclonal antibodies to hirudin and hirudin peptides. A mehtod for studying the hirudin-thrombin interacton/J.-M. Schlaeppi, S. Vekemans, H. Rink, J.-Y. Chang // Eur. J. Biochem.-1990.-188, N 2-P. 463-470.

36. Krstenansky J. L., Mao S. J. T. Antithrombin properties of C-terminus of hirudin using synthetic insulfated Na-acetyl-hirudin using 45-65//FEBS Lett.-1987.-$211, N 1 .-$ P. $10-16$

37. $N$-rerminal requirements of small peptide anticoagulants based on hirndin $54-65 /$ T. J. Owen, J. L. Krstenansky, M. T. Yates, J. T. Mao//J. Med. Chem. - 1988. .N 5.-P. 1009-1011.

38. Interaction of hirudin with thrombin: identification of minimal binding donain of hirndin that inhibits clotting activity/S. J. T. Mao, M. T. Yates, T. J. Owen, J. L. Krstenansky // Biochemistry - 1988-27, N 21.-P. 8170-8173.

39. Anticoagulant activity of synthetic hirudin peptides/J. M. Maraganore, B. Chao, M. L. Joseph et al.//J. Biol. Chen.-264, N 15.-P. 8692-8698.

40. Binnie C. G., Erickson B.W., Hermans J. Inhibition of thrombin by synthetic hirudin peptides // FEBS Lett.-1990.- N 1/2.- P. 85-89.

41. Bourdon P., Fenton J. W. II, Maraganore J. M. Affinity labelling of lysine- 149 in the anion-binding exosite of human $\alpha$-thrombin with $\mathrm{N}$ (dinitrofluorobenzyl)hirudin $\mathrm{C}$ lerminal peptide // Biochenistry-1990... 29, N 27.- P. 6370-6384.

42. Konno S., Fenton J.W. II, Villanueva $G$. B. Analysis of the socondary structure of hirudin and the mechanism its interaction with thrombin// Arch. Biochem. and Biop. liss. - 1988-267, N 1.- P. 158-166

43. Ni F., Konishi Y., Scheraga H. A. Thrombin-bound conformation of the C-terminal fragments of lirudin determined by transferred nuclear Overhauser effects // Biochemistry.-1990.-29. N 18.- P. 4479-4489.

44. Crystal structure of the thrombin-hirudin complex: a novel mode of serine protease inhibition / M. G. Grütter, J. P. Priestle, J. Rahnel et al.-- // EMBO J.-1990-9, N 8.- P. $2361-2365$

45. The structure of a complex of recombinant hirudin and human $\alpha$-thrombin / T. J. Rydel, K. G. Ravichandran, $A$. Tulinsky et al.// Science. - 1990.-249, N 4966. P. $277-280$.

46. The effect of hirudin on endotoxin induced disscminated intratascular coagulation (DIC) $/ \Lambda$. Ishikawa, R. Hafter, U. Seemüller et al.// Thromb. Res. -1980 . - 19, N 3.- P. $351-358$

47. Pharmacological studies on the antithrombotic action of herudin in experimental animals/F. Markwardt, J. Hauptmann, G. Novak et al.//Thromb. Hacmostas. 1982.-47, N 3.- P. 226-229.

48. Pharmacokinetics and anticoagulant effects of hifudin in man//F. Markwardt, G. Novak, J. Stürrebecher et al. // Ibid - 1984-52, N 2-P. 160-163

19. Narkwarlt $F$. Pharmacology of selective thrombin inlibitors//Now. Rev. Fr. Hematol. - 1988. - 30.-P. $161^{165} 16$.

50. Cloning and expression in $E$. coli of a synthetic DNA for hirudin the blood coasulation inhibitor in the Leech / E Fortkamp, M. Reiger, G. Husisterberg-Mautses of al. // DN $1.1986 ;-5$, N 6.- P. $511-517$.

51. Cloning and expression of a cDNA coding for anticoagulant hirudin from the Bto. odsucking lecch. Hirudo medicinalis/R. P. Harvey, E., Degryse, L. Steiani ct al.// Proc. Nat. Ac ad. Sci. USA - 1986-83, N 4-P. 1084-1088.

52. Expression and secretion in $S$ cerevisiae of biologically leech hirudin/G. I_oison, A. Findeli. S. Bernard et al.// Bio/Techonology - 1988-6, N 1.- P. 72-77.

53. Degryse E. Determination of the specific activity of recombinant hirudin//Thromb. Res.-1990.60, N 6.-P. $433-443$

54. Hortin G. L.. Benuth B. M. Inhibition of thrombins clotling activity hy synthetio peptide segments of its inhibitors and substrates // Biochem. and Biophys. Res. Com muns - 1990.-. 169, N 2.-P. 437-442.

55. Pat. 299576 USA, IC A6IK37/02, C O7K 7/10/G. L. Hortin (23.01.89)//P尔 «ФU зико-химнческая бнология н биотехнопогня»--1990.-№ 10. Реф. 10А208П.

56. Design and characterization of hirulogs: a novel class of bivalent peptide ininibitors of thrombin/J. M. Maraganore, P. Bourdon, J. Jablonski et al.// Biochemistry. 1990. - 29, N 30.-P. 7095-710i

Ин-т бноорг. хнмии и гістехнмия $А$ У

Получсно 30.07 .91 